\title{
Exposure to Air Pollution inside Electric and Diesel-Powered Passenger Trains
}

Guerra Andersen, Maria Helena; Johannesson, Sandra; Fonseca, Ana Sofia; Clausen, Per Axel; Saber, Anne Thoustrup; Roursgaard, Martin; Löschner, Katrin; Koponen, Ismo K; Loft, Steffen; Vogel, Ulla Birgitte

Total number of authors:

11

Published in:

Environmental Science and Technology

Link to article, DOI:

10.1021/acs.est.8b06980

Publication date:

2019

Document Version

Peer reviewed version

Link back to DTU Orbit

Citation (APA):

Guerra Andersen, M. H., Johannesson, S., Fonseca, A. S., Clausen, P. A., Saber, A. T., Roursgaard, M.,

Löschner, K., Koponen, I. K., Loft, S., Vogel, U. B., \& Møller, P. (2019). Exposure to Air Pollution inside Electric and Diesel-Powered Passenger Trains. Environmental Science and Technology, 53(8), 4579-4587.

https://doi.org/10.1021/acs.est.8b06980

\section{General rights}

Copyright and moral rights for the publications made accessible in the public portal are retained by the authors and/or other copyright owners and it is a condition of accessing publications that users recognise and abide by the legal requirements associated with these rights.

- Users may download and print one copy of any publication from the public portal for the purpose of private study or research.

- You may not further distribute the material or use it for any profit-making activity or commercial gain

- You may freely distribute the URL identifying the publication in the public portal 


\section{Exposure to air pollution inside electric and diesel-powered passenger trains}

Maria Helena Guerra Andersen, Sandra Johannesson, Ana Sofia Fonseca,

Per Axel Clausen, Anne Thoustrup Saber, Martin Roursgaard, Katrin

Löschner, Ismo Kalevi Koponen, Steffen Loft, Ulla Vogel, and Peter Moller

Environ. Sci. Technol., Just Accepted Manuscript • DOI: 10.1021/acs.est.8b06980 • Publication Date (Web): 27 Mar 2019

Downloaded from http://pubs.acs.org on March 29, 2019

\section{Just Accepted}

"Just Accepted" manuscripts have been peer-reviewed and accepted for publication. They are posted online prior to technical editing, formatting for publication and author proofing. The American Chemical Society provides "Just Accepted" as a service to the research community to expedite the dissemination of scientific material as soon as possible after acceptance. "Just Accepted" manuscripts appear in full in PDF format accompanied by an HTML abstract. "Just Accepted" manuscripts have been fully peer reviewed, but should not be considered the official version of record. They are citable by the Digital Object Identifier (DOIß). "Just Accepted" is an optional service offered to authors. Therefore, the "Just Accepted" Web site may not include all articles that will be published in the journal. After a manuscript is technically edited and formatted, it will be removed from the "Just Accepted" Web site and published as an ASAP article. Note that technical editing may introduce minor changes to the manuscript text and/or graphics which could affect content, and all legal disclaimers and ethical guidelines that apply to the journal pertain. ACS cannot be held responsible for errors or consequences arising from the use of information contained in these "Just Accepted" manuscripts. 
1 Exposure to air pollution inside electric and diesel-powered passenger trains

2 Maria Helena G. Andersen ${ }^{1,2 *}$, Sandra Johannesson ${ }^{3}$, Ana Sofia Fonseca ${ }^{2}$, Per Axel Clausen ${ }^{2}$, 3 Anne Thoustrup Saber ${ }^{2}$, Martin Roursgaard ${ }^{1}$, Katrin Loeschner ${ }^{4}$, Ismo K. Koponen ${ }^{2}$, Steffen Loft ${ }^{1}$, $4 \quad$ Ulla Vogel ${ }^{2,5}$, Peter Møller ${ }^{1}$

5

$6{ }^{1}$ Department of Public Health, Section of Environmental Health, University of Copenhagen, Øster 7 Farimagsgade 5A, DK-1014 Copenhagen K, Denmark

$8{ }^{2}$ The National Research Centre for the Working Environment, Lersø Parkalle 105, DK-2100

9 Copenhagen $\varnothing$, Denmark.

$10{ }^{3}$ Department of Occupational and Environmental Medicine, Sahlgrenska Academy at University

11 of Gothenburg, 40530 Gothenburg, Sweden.

$12{ }^{4}$ National Food Institute, Technical University of Denmark, DK-2800 Kgs. Lyngby, Denmark

13 5epartment of Health Technology, Technical University of Denmark, DK-2800 Kgs. Lyngby, 14 Denmark

15 *Corresponding author: mhar@sund.ku.dk; mga@nfa.dk

17 Keywords

18 Diesel exhaust, diesel train, personal exposure, ultrafine particles, black carbon, nitrogen oxides, 19 underground station, commuter 
Table of contents/Abstract art
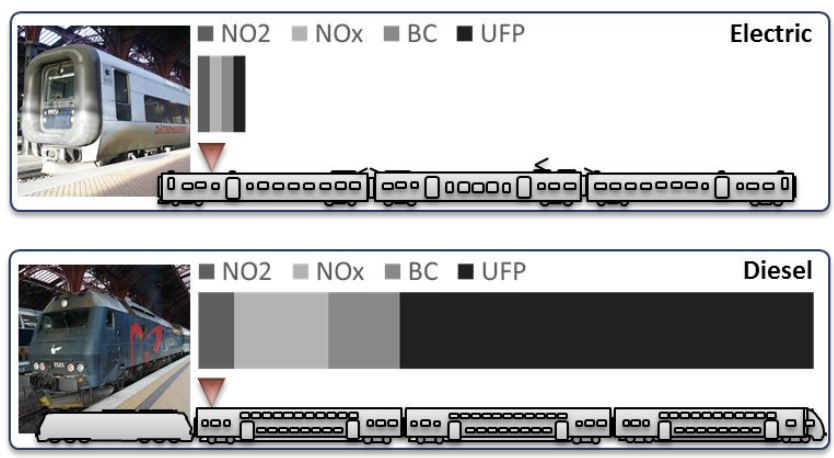

\section{Abstract}

Diesel-powered trains are used worldwide for passenger transport. The present study aimed to assess air pollution concentrations in passenger cars from diesel and electric trains. Personal exposure monitoring (6-7 hours per day) was carried out for 49 days on diesel and 22 days on electric trains. Diesel trains had higher concentrations of all the assessed air pollution components. Average increases (and fold differences) in passenger cars of diesel trains compared with electric trains were for ultrafine particles 212,000 particles $/ \mathrm{cm}^{3}$ (35-fold), black carbon $8.3 \mu \mathrm{g} / \mathrm{m}^{3}$ (6-fold), $\mathrm{NO}_{\mathrm{X}} 316 \mu \mathrm{g} / \mathrm{m}^{3}$ (8-fold), $\mathrm{NO}_{2} 38 \mu \mathrm{g} / \mathrm{m}^{3}$ (3-fold), $\mathrm{PM}_{2.5} 34 \mu \mathrm{g} / \mathrm{m}^{3}$ (2-fold) and benzo(a)pyrene 0.14 $\mathrm{ng} / \mathrm{m}^{3}$ (6-fold). From time-series data, the pull and push movement modes, the engine in use and the distance to the locomotive influenced the concentrations inside the diesel trains. In conclusion, concentrations of all air pollutants were significantly elevated in passenger cars in diesel trains compared to electric trains.

\section{Introduction}

43 Railway passenger and freight transport activity have been growing globally in the last 40 years ${ }^{1}$.

44 Electricity is the power supply of choice in trains in many areas, but a significant proportion of commuter and freight trains worldwide are still powered by diesel fuel. It has been shown that 
diesel-powered trains increase the concentrations of fine particulate matter $\left(\mathrm{PM}_{2.5}\right)$ and ultrafine particles (UFP; $<0.1 \mu \mathrm{m}$ ) in the open air close to the railway ${ }^{2,3}$. However, PM has been shown to also penetrate into passenger cars of the train ${ }^{4,5}$. A review of commuter exposure to particles reported three times higher UFP concentrations in passenger cars of diesel than electric trains, with highest concentrations when diesel-propelled locomotives operate in pull mode ${ }^{6}$ Two more recent studies also reported significant differences of UFP concentrations inside passenger cars of diesel trains depending on position of locomotive ${ }^{4,7}$. In general, high variability of UFP concentrations has been reported inside diesel trains. More knowledge on seasonal variation and other components of the complex diesel exhaust mixture penetrating to train cars is needed. Electric trains generate only particle emissions from non-exhaust sources such as wear and mechanical friction on rail tracks, wheels and brakes, as well as friction and arcing of the electrical wires. The majority of the studies on electric trains have addressed particle exposure on train platforms and tunnels ${ }^{8}$, although a few recent studies assessed exposures and factors affecting exposures inside passenger $\operatorname{cars}^{5,9}$.

61 High concentrations of diesel exhaust in passenger cars are worrying because it is associated with increased risk of lung cancer as well as other lung and cardiovascular diseases ${ }^{10-12}$. In addition to

63 passengers, train conductors, engine drivers, maintenance staff, platform staff and other train

64 personnel can be exposed. Our study was initiated because of concern about potential health

65 effects in workers and passengers who commute in diesel-powered trains. In Copenhagen,

66 Denmark, the urban train system is electrified, but co-exists with diesel-powered trains that travel 67 further on intercity routes. A recent report showed that two types of diesel rolling stock used in

68 Denmark gave rise to higher UFP exposure to staff working in the passenger cars than what would 69 occur on the most busy street in Copenhagen ${ }^{13}$. The aim of the present study was to perform a 
comprehensive comparison of the concentration levels inside passenger cars of diesel-powered and electric trains including both particulate and gaseous air pollutants.

\section{Methods}

\section{Study design}

Twenty-nine volunteers were recruited to sit inside the front car of Danish State Railways trains running in the Zealand region, carrying portable measuring devices and samplers. The concentrations characterization was performed in the same type of trains on three consecutive days each week (Tuesday, Wednesday and Thursday) for 6-7 hours per day. A pilot study was conducted during two days in March in order to characterize the size distributions, test the concentration contrast and test the chosen routes. The main study period covered a total of 23 weeks from May to December 2017. Out of the 23 monitoring weeks, seven were conducted in electric trains and 16 in diesel trains. In addition to measurements in trains, two more days of measurements were done on a busy multimodal underground train platform in Copenhagen, as a worst-case scenario used opportunistically to assess the contribution of the studied diesel trains in the underground environment.

\section{Trains and train routes}

The electric trains operated on a route from Østerport station to Elsinore station $(46 \mathrm{~km})$. The train route was taken forward and back 3 times per day, for a total of 5-hours and 37 minutes per day, including waiting time at Østerport and Elsinore stations, starting at $9 \mathrm{~h} 39$ and ending at $15 \mathrm{~h} 16$. The rolling stock is termed Litra ET and runs on alternating current in overhead power lines (25 $\mathrm{kV}$ and $50 \mathrm{~Hz}$ ). 
94 As the diesel train exposure scenario, a double deck train propelled by a diesel locomotive (Litra

ME, from 1981-85, 33 units in circulation) was chosen in a route from Østerport to Kalundborg station $(114 \mathrm{~km})$, return to Copenhagen Central Station, and from there to Holbæk (part of Kalundborg line, $68 \mathrm{~km}$ ) and back to Copenhagen Central Station. The route took a total of 7 hours per day, including waiting time at the stations, starting at $8 \mathrm{~h} 34$ and ending at $15 \mathrm{~h} 32$. This route was chosen because the same locomotive was used all the day (defined as "diesel A"). For the measurements in October and November, the trip was firstly heading to Holbæk and then to Kalundborg, driven with three different ME locomotives and saving one hour of waiting time at the station (defined as "diesel B"). The driving locomotive code was noted every day for the diesel scenario. The diesel routes include a passage at one underground station in the Copenhagen city centre (Nørreport Station). The plan for the different weeks and schedules are available in supporting information (SI, Tables S1 and S2).

The windows in both passenger train cars (electric and diesel) were sealed and could not be opened. Furthermore, the ventilation system was not passenger-adjustable.

\section{Underground station}

The underground train platform at Nørreport station is a $200 \mathrm{~m}$ long single platform positioned between two tracks. It is equipped with a modern ventilation system (from 2014) and serves both electric and diesel regional and intercity trains. Measurements were carried out on two different days: on the first day (Friday January $26^{\text {th }}$ ) all train types were running as usual, but on the second day (Friday February $2^{\text {nd }}$ ) all ME locomotives had been taken out of circulation for maintenance, providing a unique opportunity to perform measurements at the underground station both with and without the ME-diesel locomotives. The monitoring instruments were maintained in the same 
position on the train platform for 4 hours. The train passages were noted for both tracks in both

119 days.

\section{Measurements, instrumentation and chemical analyses}

122 All air pollution measurements were performed as personal monitoring with the volunteers

123 carrying the equipment. In the diesel trains the volunteers were sitting in the compartment in the 124 front section of the first passenger car (Figure S2) and in the electric trains they were sitting in the 125 first passenger car. Black carbon mass concentration (BC) and UFP number concentration were 126 measured on each monitoring day during the total period of the study, both on-board of the diesel 127 and electric trains and on the platform of the underground station. Nitrogen oxides $\left(\mathrm{NO}_{2}\right.$ and $\mathrm{NO}_{\mathrm{x}}$; 128 whole period), aldehydes (10 weeks from May to September), $\mathrm{PM}_{2.5}$ and polycyclic aromatic 129 hydrocarbons (PAHs; 9 weeks in October and November) were sampled on-board of the electric 130 and diesel trains (Table S1). Additionally, PM was collected by means of a mid-volume 131 electrostatic sampler, described elsewhere ${ }^{14}$, in the compartment in the front train car during the 132 monitoring weeks in December. Measurements to investigate concentration gradient inside the 133 trains were performed for three days, where one person sat in the compartment in the front section 134 of the first passenger car, while another person sat each day at a different position in the lower 135 deck of the train (for entire day trip), each of them carrying one BC and one UFP measuring 136 device. A summary of the measurements, instruments, periods and sites monitored as well as time 137 resolutions and flows used is presented in SI (Table S3).

Black carbon

140 Black carbon was measured with 1-minute resolution using two MicroAeth AE51 aethalometers 141 (Aethlabs, San Francisco, CA) with high degree of comparability (correlation coefficient, r=0.95). 
142 The filters inside the aethalometer were changed after each monitoring day in the diesel trains, and 143 after the three monitoring days in the electric trains.

\section{Ultrafine particles}

146 UFP concentrations were measured using both diffusion chargers DiSCmini (DM; DiSCmini,

147 Matter Aerosol AG, Wohlen, Switzerland) and NanoTracer (NT; Aerasense NanoTracer, Oxility, 148 Eindhoven, the Netherlands). For the two-day pilot study the NanoScan SMPS model 3910 (TSI, 149 Shoreview, MN, USA) was also used. The devices were synchronized with a working computer's 150 clock. Two DM devices were used for the gradient measurements with high degree of 151 comparability $(\mathrm{r}=0,96)$. Measurement time resolutions were 1-second for DM, 16-seconds for NT 152 and 1-minute for NanoScan SMPS (Table S3).

\section{Nitrogen oxides}

155 Passive Ogawa samplers (Ogawa, FL, USA) were used for personal sampling of nitrogen oxides.

156 Two samplers were used over the three consecutive days in each exposure scenario and kept in 157 sealed plastic bags overnight at $4^{\circ} \mathrm{C}$ (and after completed sampling). Samplers were analysed by 158 ion chromatography and corrected with field blanks ${ }^{15}$. The limit of detection (LOD) for the 159 sampling time of $18-21$ hours was $0.7 \mu \mathrm{g} / \mathrm{m}^{3}$ for $\mathrm{NO}_{2}$ and $1.4 \mu \mathrm{g} / \mathrm{m}^{3}$ for $\mathrm{NO}_{\mathrm{x}}$. None of the samples 160 were below the LOD.

162 Aldehydes

163 Aldehydes were measured with Sep-Pak XPoSure aldehyde samplers (Waters, MA, USA)

164 connected to pumps. The samplers were closed with caps and kept overnight at $4^{\circ} \mathrm{C}$ during the 165 three cumulated sampling days for each exposure scenario and in the end kept at $-20^{\circ} \mathrm{C}$. The 166 samplers were analysed for 13 different aldehydes and one ketone using high-performance liquid 
chromatography with UV detection. The sampled air volume was $0.21-0.27 \mathrm{~m}^{3}$ and the LOD was $0.5 \mu \mathrm{g} / \mathrm{sample}$ for each substance.

$\mathrm{PM}_{2.5}$ was collected on filters (Teflon w/ring PALL $2.0 \mu \mathrm{m}, 37 \mathrm{~mm}$ ) using a cyclone (Triplex cyclone, BGI, USA) at $1.5 \mathrm{~L} / \mathrm{min}$. A sequence set of two XAD-2 tubes (sample + backup tube) for sampling of gaseous PAHs were attached after the cyclone (Figure S1). After the sampling week was completed, the XAD-2 tubes were wrapped in aluminium foil and kept at $-20^{\circ} \mathrm{C}$. The filter cassettes were wrapped in aluminium foil and kept in the dark, dry and at room temperature before and after use. The Teflon filters were weighed before and after sampling in controlled climate conditions. LOD for particle mass was $29 \mu \mathrm{g}$. Two filters were excluded due to sampling failure and/or failure in the chemical analysis.

Particles on filters were extracted and analysed for the content of 16 US EPA priority PAHs

(Table S5) using high-resolution gas chromatography/low-resolution mass spectrometry ${ }^{16}$. Field blanks were analysed along with the samples, and certified reference material was used for quality control. The XAD-2 from the sample and backup tube were combined and sonicated with $5 \mathrm{~mL}$ cyclohexane for 60 minutes and analyzed by gas chromatography-mass spectrometry for the same PAHs as in filters, analyzed in a different laboratory as previously described ${ }^{17}$. LODs for gaseous PAHs were 0.1-0.6 pg/ $\mu \mathrm{L}$ extract depending on the individual PAH.

PM metal content

189 PM collected with the electrostatic sampler in weeks 23 and 24 in diesel A scenario was analysed 190 for the content of 24 elements by inductively coupled plasma mass spectrometry. Detailed 191 information is available in SI, Table S6. 
Time-series data analyses

194 The time-series data from BC, DM and NT (also from NanoScan, for the pilot study) were 195 synchronized in start and ending times and grouped by scenario (diesel A, diesel B and electric). 196 The BC data were collected with two duplicate devices, which were averaged for each measured 197 resolution unit (minute). Data for each monitoring day from each device were aggregated in 10 198 minutes intervals and the time slots of the different days were averaged. The averages and 199 percentiles for each 10-minute average concentration over time of the day within each scenario 200 were then plotted, as well as 10 -minute maximum values using $\mathrm{R}$ statistical language ${ }^{18}$. The $\mathrm{BC}$ 201 and DM time-series from the concentration gradient measurements and from the underground 202 station were kept and re-sampled in the smallest time resolution possible for comparison (i.e. 1 203 minute). Some of the monitoring days were excluded from the analysis (Table S4).

\section{Statistics}

206 The Welch t-test was used to compare the concentrations in diesel and electric scenarios using $\mathrm{R}$ 207 statistical language ${ }^{18}$. The average of daily 10-minute slots for all days measured was used for 208 calculating the mean, SD and range for time-series data from $\mathrm{BC}$ and UFP. The average 209 concentration of the two duplicate personal samplers used per week was used for calculating the 210 mean concentrations, $\mathrm{SD}$ and the range in concentrations for $\mathrm{NO}_{\mathrm{x}}, \mathrm{NO}_{2}$, aldehydes, $\mathrm{PM}_{2.5}$ and the 211 PAHs.

\section{Results}

\section{On-board the trains}

Black carbon and ultrafine particles 
216 Total particle number concentration and average size of UFP were measured in a pilot study in

217 Diesel A scenario with three different devices, showing similar readings of particle number

218 concentrations between devices (Figure S3). Detailed output figures from the NanoScan SMPS

219 device from both electric and diesel pilot measurements are in SI (Figures S4 and S5). For

220 personal monitoring in the main study the NanoScan device was not used since it is less portable.

222 Figure 1 shows the mean daily particle concentration patterns inside the train in the Diesel A,

223 Diesel B and Electric exposure scenarios. The patterns for BC mass concentrations and UFP

224 number concentrations (measured by DM equipment) showed similar trends (with daily averages

225 from both devices with $\mathrm{r}=0.75$ ). The NT measurements were similar to the DM data and are

226 shown in SI (Figure S6). For both BC and UFP in the Diesel A scenario, a large increase in

227 concentrations was observed between $8 \mathrm{~h} 30$ and $10 \mathrm{~h}$, and a small increase between $13 \mathrm{~h} 30$ and

228 14h30. A similar trend was observed for the Diesel B scenario, with the second peak appearing

229 earlier in the day. The increased concentrations of BC and UFP in both diesel scenarios occurred

230 when the locomotive was pulling the train (leaving Copenhagen) and the lower concentrations

231 when the locomotive was pushing the train (returning to Copenhagen). When the locomotive was

232 in front, higher concentrations of BC and UFP were measured inside the passenger car with

233 average particle number concentrations of around 400,000 particles $/ \mathrm{cm}^{3}$ and $\mathrm{BC}$ mass

234 concentration exceeding $20 \mu \mathrm{g} / \mathrm{m}^{3}$. For the 10 -minutes average maximums, the UFP

235 concentrations exceeded 2 million particles $/ \mathrm{cm}^{3}$ and BC mass concentration was $70-100 \mu \mathrm{g} / \mathrm{m}^{3}$

236 (Figure 1). When the locomotive was in push mode the averaged concentrations were 10,000-

23730,000 particles $/ \mathrm{cm}^{3}$ and 2-3 $\mu \mathrm{g} / \mathrm{m}^{3} \mathrm{BC}$. The concentrations of BC and UFP inside the electric

238 trains were considerably lower than in the diesel trains. A small increase in concentrations could

239 be observed when the train was at Østerport station in Copenhagen, in the beginning and end of

240 the measurements, and also in the time intervals $11 \mathrm{~h} 16-11 \mathrm{~h} 39$ and $13 \mathrm{~h} 16-13 \mathrm{~h} 39$ when the 
241 volunteers waited on the Østerport station platform to change trains. At the terminal station for

242 electric trains in Elsinore, the concentrations were at the same level as when the train was in

243 movement (between 3,000-7,000 particles $/ \mathrm{cm}^{3}$ and $0.5-4 \mu \mathrm{g} / \mathrm{m}^{3} \mathrm{BC}$ ), while at Østerport station,

244 shared with diesel trains, the averaged concentrations were $10,000-13,000$ particles $/ \mathrm{cm}^{3}$ and 3-5

$245 \mu \mathrm{g} / \mathrm{m}^{3} \mathrm{BC}$. Table 1 summarizes the daily averaged concentrations of BC and UFP for diesel (both

246 diesel A and B) versus electric scenario and Table 2 shows the differences between movement

247 mode (pull/push, forward/backward, for diesel and electric) and for the different train scenarios

248 (diesel A, diesel B and electric). For BC, concentrations were 6-fold higher in the diesel compared 249 to the electric scenario and for UFP 35- and 20-fold higher (measured with DM and NT,

250 respectively).

Black carbon
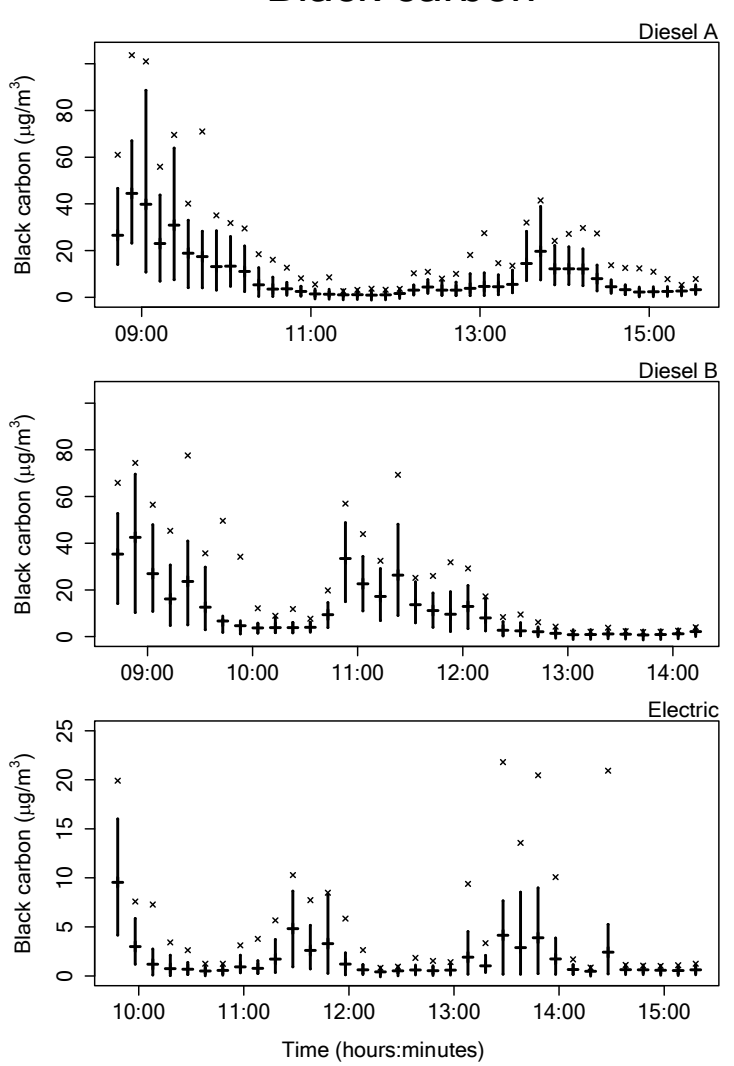

Ultrafine particles
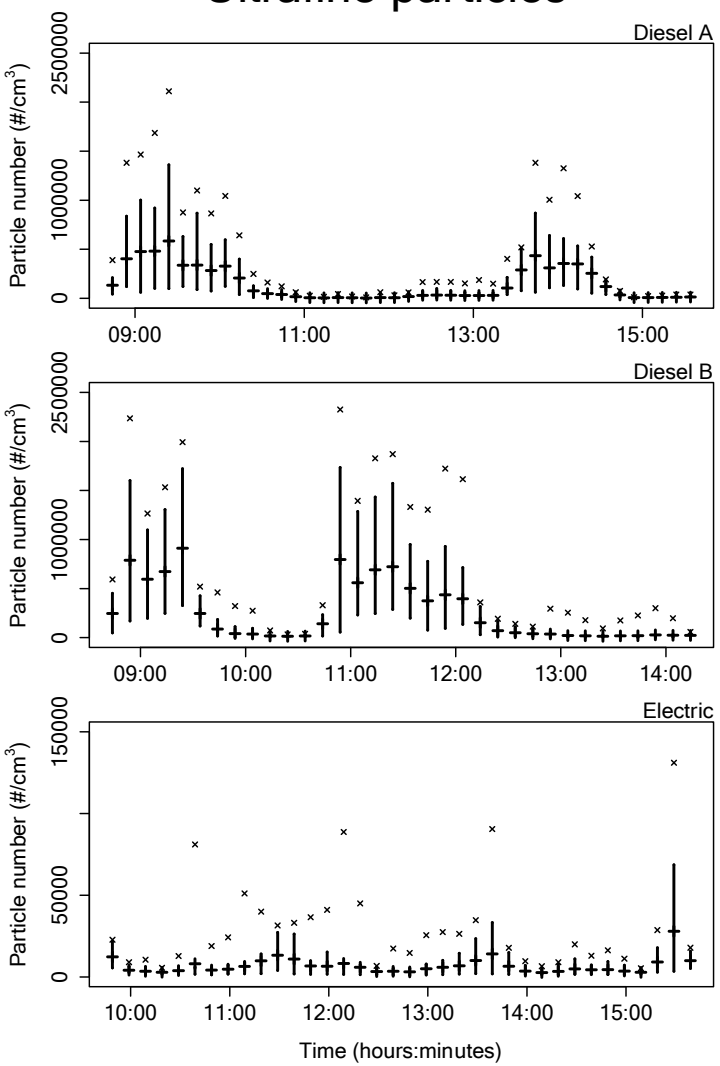

Figure 1 - Daily temporal BC mass concentrations and UFP number concentrations (measured by 
arithmetic mean (horizontal lines), the $10^{\text {th }}$ to $90^{\text {th }}$ percentile distributions (vertical lines), and the

maximum values (point crosses) for the 10 minutes averaged data. $\mathrm{BC}$ data were collected from 28

257 monitoring days for the Diesel A scenario, for 17 days for the Diesel B scenario and 18 days for the Electric scenario. UFP data were collected from 21 days for Diesel A, 18 days for Diesel B and 17 days for Electric (Table S4 presents missing data). Note the different y-axis ranges for diesel and electric trains.

Table 1 - Black carbon, ultrafine particles, nitrogen oxides, aldehydes, $\mathrm{PM}_{2.5}$ mass concentration and PAHs in particles mass and gas phase, respectively.

\begin{tabular}{|c|c|c|c|c|c|c|c|c|}
\hline & \multicolumn{3}{|c|}{ Diesel train } & \multicolumn{3}{|c|}{ Electric train } & \multirow{2}{*}{$\begin{array}{c}\text { Fold } \\
\text { difference } \\
\text { (diesel vs } \\
\text { electric) }\end{array}$} & \multirow{2}{*}{$\begin{array}{c}\text { Mean } \\
\text { difference } \\
\text { (CI 95\%) }\end{array}$} \\
\hline & $\mathbf{n}$ & $\operatorname{Mean} \pm \mathrm{SD}^{1}$ & Range $^{1}$ & $\mathbf{n}$ & $\operatorname{Mean} \pm$ SD $^{1}$ & Range $^{1}$ & & \\
\hline $\begin{array}{l}\text { Black carbon } \\
\left(\mu \mathrm{g} / \mathrm{m}^{3}\right)\end{array}$ & 21 & $10.0 \pm 3.3$ & $3.8-15.1$ & 7 & $1.7 \pm 0.6$ & $1.2-3.2$ & 6 & $\begin{array}{l}8.3(7.3 ; \\
9.3)^{* * * *}\end{array}$ \\
\hline $\begin{array}{l}\text { UFP from DM } \\
\left(\# / \mathrm{cm}^{3}\right)\end{array}$ & 15 & $\begin{array}{c}218,000 \pm \\
140,000\end{array}$ & $\begin{array}{l}31,700- \\
560,000\end{array}$ & 6 & $\begin{array}{l}6,150 \pm \\
2,310\end{array}$ & $\begin{array}{l}4,100- \\
12,700\end{array}$ & 35 & $\begin{array}{c}212,000 \\
(167,000 \\
257,000)^{* * *}\end{array}$ \\
\hline $\begin{array}{l}\text { UFP from NT } \\
\left(\# / \mathrm{cm}^{3}\right)\end{array}$ & 17 & $\begin{array}{l}153,000 \pm \\
81,000\end{array}$ & $\begin{array}{l}29,200- \\
425,000\end{array}$ & 7 & $\begin{array}{l}7,760 \pm \\
4,200\end{array}$ & $\begin{array}{l}3,670- \\
22,600\end{array}$ & 20 & $\begin{array}{c}145,000 \\
(121,000 \\
169,000)^{* * *}\end{array}$ \\
\hline $\mathrm{NO}_{\mathrm{x}}\left(\mu \mathrm{g} / \mathrm{m}^{3}\right)$ & 14 & $364 \pm 81$ & $275-531$ & 7 & $48 \pm 16$ & $25-65$ & 8 & $\begin{array}{c}316(268 \\
365)^{* * *}\end{array}$ \\
\hline $\mathrm{NO}_{2}\left(\mu \mathrm{g} / \mathrm{m}^{3}\right)$ & 14 & $53 \pm 16$ & $35-99$ & 7 & $16 \pm 10$ & $6-31$ & 3 & $38(26 ; 49)^{* * *}$ \\
\hline $\begin{array}{l}\text { Aldehydes } \\
\text { (sum) }\left(\mu \mathrm{g} / \mathrm{m}^{3}\right)\end{array}$ & 6 & $50 \pm 8$ & $37-59$ & 4 & $41 \pm 2$ & $39-44$ & 1.2 & $\mathrm{NC}^{2}$ \\
\hline $\begin{array}{l}\text { Formaldehyde } \\
\left(\mu \mathrm{g} / \mathrm{m}^{3}\right)\end{array}$ & 6 & $9.0 \pm 2.1$ & $6.4-11.4$ & 4 & $5.2 \pm 0.3$ & $4.8-5.5$ & 1.7 & $\mathrm{NC}^{2}$ \\
\hline $\mathrm{PM}_{2.5}\left(\mu \mathrm{g} / \mathrm{m}^{3}\right)$ & 6 & $68 \pm 15$ & $51-96$ & 3 & $32 \pm 7$ & $24-37$ & 2 & $\mathrm{NC}^{2}$ \\
\hline $\begin{array}{l}\sum \mathrm{PAH} \text { in } \\
\mathrm{PM}_{2.5}\left(\mathrm{ng} / \mathrm{m}^{3}\right)\end{array}$ & 6 & $1.7 \pm 0.6$ & $1.0-2.5$ & 3 & $0.31 \pm 0.13$ & $0.21-0.45$ & 6 & $\mathrm{NC}^{2}$ \\
\hline $\begin{array}{l}\mathrm{BaP}\left(\mathrm{ng} / \mathrm{m}^{3}\right) \text { in } \\
\mathrm{PM}_{2.5}\end{array}$ & 6 & $0.17 \pm 0.09$ & $0.08-0.30$ & 3 & $0.03 \pm 0.003$ & $0.028-0.034$ & 6 & $\mathrm{NC}^{2}$ \\
\hline $\begin{array}{l}\sum \text { PAH XAD- } \\
2 \text { tubes } \\
\left(\mathrm{ng} / \mathrm{m}^{3}\right)\end{array}$ & 6 & $165 \pm 56$ & $110-261$ & 3 & $146 \pm 48$ & $116-201$ & 1.1 & $\mathrm{NC}^{2}$ \\
\hline $\begin{array}{l}\text { Naphthalene } \\
\text { XAD-2 tubes }\end{array}$ & 6 & $134 \pm 26$ & $99-170$ & 3 & $108 \pm 55$ & $67-170$ & 1.2 & $\mathrm{NC}^{2}$ \\
\hline
\end{tabular}


$\left(\mathrm{ng} / \mathrm{m}^{3}\right)$

$\mathrm{n}$, number of weeks sampled (3 days per week); SD, standard deviation; CI, confidence interval;

265 UFP, ultrafine particles; DM, DiscMini; NC, not calculated; NT, NanoTracer; $\sum$ PAH, total

266 amount of PAH in particles collected on filter or collected in the XAD-2 tubes; BaP,

267 benzo(a)pyrene. ${ }^{1}$ Mean and Range determined from values over daily averages of 10 -minute time

268 periods; ${ }^{2}$ Limited number of samples to calculate a reliable mean difference. Diesel trains include

269 both scenarios $\mathrm{A}$ and $\mathrm{B} ; * * * \mathrm{p}<0.001$

Table 2 - Black carbon and ultrafine particle concentrations for movement mode and scenario

\begin{tabular}{|c|c|c|c|c|c|c|c|}
\hline & & \multicolumn{2}{|c|}{ Pull mode/forward } & \multicolumn{2}{|c|}{ Push mode/backward } & \multirow{2}{*}{$\begin{array}{c}\text { Fold } \\
\text { difference } \\
\text { (pull vs } \\
\text { push) }\end{array}$} & \multirow{2}{*}{$\begin{array}{c}\text { Mean } \\
\text { difference }(\mathrm{CI} \\
95 \%)\end{array}$} \\
\hline & & Mean $\pm S D^{1}$ & Range $^{1}$ & Mean $\pm S D^{1}$ & Range $^{1}$ & & \\
\hline \multirow{3}{*}{ 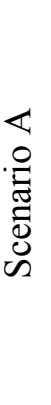 } & $\begin{array}{l}\text { Black carbon } \\
\left(\mu \mathrm{g} / \mathrm{m}^{3}\right)\end{array}$ & $19.8 \pm 10.7$ & $8.0-44.5$ & $2.0 \pm 0.9$ & $0.9-3.3$ & 10 & $\begin{array}{c}17.8(12.1 \\
23.5)^{* * *}\end{array}$ \\
\hline & $\begin{array}{l}\text { UFP from } \\
\text { DM }\left(\# / \mathrm{cm}^{3}\right)\end{array}$ & $\begin{array}{c}347,600 \pm \\
111,200\end{array}$ & $\begin{array}{l}132,400- \\
583,500\end{array}$ & $\begin{array}{c}10,400 \pm \\
7,800\end{array}$ & $\begin{array}{l}3,300- \\
34,000\end{array}$ & 33 & $\begin{array}{c}337,200 \\
(278,000 ; \\
396,600)^{* * *}\end{array}$ \\
\hline & $\begin{array}{l}\text { UFP from } \\
\text { NT }\left(\# / \mathrm{cm}^{3}\right)\end{array}$ & $\begin{array}{c}279,500 \pm \\
88,000\end{array}$ & $\begin{array}{l}128,000- \\
500,200\end{array}$ & $\begin{array}{c}13,100 \pm \\
12,000\end{array}$ & $\begin{array}{l}5,200- \\
53,800\end{array}$ & 21 & $\begin{array}{c}266,400 \\
(219,000 \\
313,700)^{* * *}\end{array}$ \\
\hline \multirow{3}{*}{ 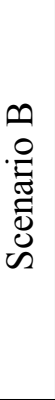 } & $\begin{array}{l}\text { Black carbon } \\
\left(\mu \mathrm{g} / \mathrm{m}^{3}\right)\end{array}$ & $20.8 \pm 10.4$ & $8.0-42.5$ & $2.5 \pm 1.8$ & $0.7-6.7$ & 8 & $\begin{array}{c}18.3(12.5 \\
24.2)^{* * *}\end{array}$ \\
\hline & $\begin{array}{l}\text { UFP from } \\
\text { DM }\left(\# / \mathrm{cm}^{3}\right)\end{array}$ & $\begin{array}{c}539,600 \pm \\
228,000\end{array}$ & $\begin{array}{l}152,400- \\
912,300\end{array}$ & $\begin{array}{c}27,600 \pm \\
18,700\end{array}$ & $\begin{array}{l}13,100- \\
87,400\end{array}$ & 20 & $\begin{array}{c}512,000 \\
(385,500 ; \\
638,600)^{* * *}\end{array}$ \\
\hline & $\begin{array}{l}\text { UFP from } \\
\text { NT }\left(\# / \mathrm{cm}^{3}\right)\end{array}$ & $\begin{array}{c}400,400 \pm \\
130,800\end{array}$ & $\begin{array}{c}185,200- \\
656,300\end{array}$ & $\begin{array}{c}26,000 \pm \\
23,000\end{array}$ & $\begin{array}{l}11,500- \\
103,600\end{array}$ & 15 & $\begin{array}{c}374,400 \\
(301,200 \\
447,500)^{* * *}\end{array}$ \\
\hline \multirow{3}{*}{ 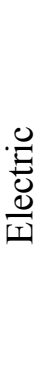 } & $\begin{array}{l}\text { Black carbon } \\
\left(\mu \mathrm{g} / \mathrm{m}^{3}\right)\end{array}$ & $1.1 \pm 0.8$ & $0.4-3.0$ & $0.9 \pm 0.5$ & $0.5-1.9$ & 1.2 & $0.3(0.4 ; 0.9)$ \\
\hline & $\begin{array}{l}\text { UFP from } \\
\text { DM }\left(\# / \mathrm{cm}^{3}\right)\end{array}$ & $\begin{array}{c}4,500 \pm \\
1,900\end{array}$ & $2,700-8,300$ & $5,500 \pm 2,200$ & $\begin{array}{l}2,800- \\
9,900\end{array}$ & 0.8 & $960(900 ; 2,900)$ \\
\hline & $\begin{array}{l}\text { UFP from } \\
\text { NT }\left(\# / \mathrm{cm}^{3}\right)\end{array}$ & $\begin{array}{c}5,200 \pm \\
1,400\end{array}$ & $4,000-8,000$ & $7,400 \pm 5,700$ & $\begin{array}{l}3,900- \\
24,000\end{array}$ & 0.7 & $\begin{array}{c}2,200(1,500 \\
5,900)\end{array}$ \\
\hline
\end{tabular}


272 SD, standard deviation; CI, confidence interval; UFP, ultrafine particles; DM, DiscMini; NT,

273 NanoTracer; ${ }^{1}$ Mean and Range determined from values over daily averages of 10 -minutes data

274 collected with trains in movement, excluding time at station. The 10-minute resolution averages

275 were not completely synchronized with the real position of the train, but buffered with time at

276 station; $* * * \mathrm{p}<0.001$

Nitrogen oxides

$279 \mathrm{NO}_{\mathrm{x}}$ on board the diesel trains was nearly 8 times higher than on the electric trains (Table 1 and

280 Figure 2). $\mathrm{NO}_{2}$ concentrations were about 3-fold higher on the diesel trains compared with the

281 electric trains. There was a trend of increasing concentrations of $\mathrm{NO}_{2}$ during the two last weeks of 282 the project (end of November).
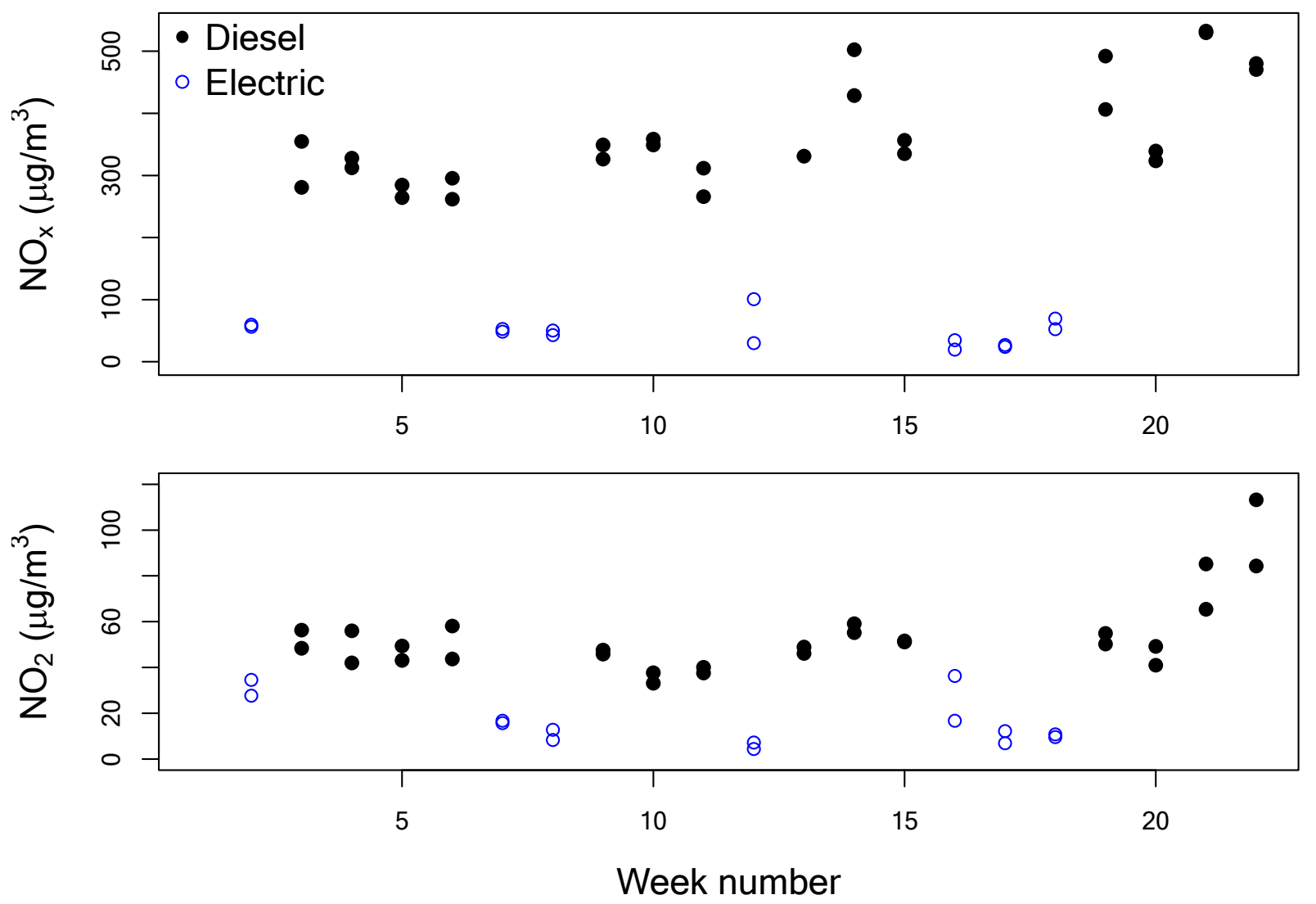

Figure $2-\mathrm{NO}_{\mathrm{x}}$ (upper) and $\mathrm{NO}_{2}$ (lower) air concentrations on board the diesel and the electric trains. Each point represents the average air concentration over the three consecutive days, 
collected with two personal samplers per week. Week numbers are reference numbers for dates presented in supporting information (Table S1)

\section{Aldehydes}

The concentrations of aldehydes were very low, and therefore these samplings were discontinued 291 after 10 weeks. For eight of the 13 analysed aldehydes (and acetone), all or the majority of the samples were below the LOD. The other six (acetaldehyde, acetone, decanal, formaldehyde, hexanal and nonanal) are presented as aldehyde total sum (Table 1). The mean concentration of formaldehyde was 1.7-fold higher in the diesel than electric trains (Table 1).

$P M_{2.5}$ and polycyclic aromatic hydrocarbons

Five filter samples had mass levels below LOD (all corresponded to the electric scenario). The mean concentrations of $\mathrm{PM}_{2.5}$ inside the diesel trains were 2-fold higher than inside the electric trains. Concentrations of benzo(a)pyrene $(\mathrm{BaP})$ and the sum of particle-bound PAHs were 6-fold higher in diesel than in electric trains (Table 1). Among the 16 PAHs analysed in the particle mass, seven were quantified in all filters from both diesel and electric trains (pyrene, benz(a)anthracene, benzo(b)fluoranthene, benzo(k)fluoranthene, benzo(a)pyrene, indeno(1,2,3cd)pyrene and benzo(g,h,i)perylene), whereas four were only found on filters from the diesel scenario (acenaphthylene, fluoranthene, chrysene and dibenz(a,h)anthracene). Among the PAHs in 305 gas-phase (XAD-2), naphthalene was the only compound measured in all samples. Six other 306 PAHs were detected in some of the samples, both from diesel and electric scenarios, with pyrene only detected in diesel scenario. PAHs with molecular weight higher than pyrene (MW=202) were not detectable in any of the XAD-2 tubes. Results in SI Table S5. 
311 The results from elemental analysis of acid extracts from PM collected in diesel trains during 6

312 days in December are presented in SI (Table S6) showing iron as the most abundant element

313 measured ( $\sim 4 \mathrm{mg} / \mathrm{g})$, followed by zinc $(\sim 3 \mathrm{mg} / \mathrm{g})$, magnesium $(\sim 2 \mathrm{mg} / \mathrm{g})$ and copper $(\sim 1.5 \mathrm{mg} / \mathrm{g})$,

314 and with higher metal contents than the standard diesel exhaust particle SRM2975. The analysis

315 was made using $2.35 \mathrm{mg}$ PM of $100 \mathrm{mg}$ collected in total.

\section{Gradient on-board the diesel train}

318 Figure 3 shows the concentrations of BC and UFP at four different positions inside the train.

319 Position 1 was used as the reference position, where the volunteers were sitting in the main study

320 (Figure S2). The measured concentrations at this first position and at position 2, just next to the

321 first compartment, were similar, with a slightly lower average of the 6-hours of measurements on position 1, although the maximum values corresponded to position 1, both for particle number and BC mass concentrations (Tables S7 and S8). During the gradient measurements, an electrostatic

324 sampler was placed at position 1 for the collection of PM. Even though the electrostatic sampler 325 might have had an air cleaning effect at position 1, the peaked data reflected the proximity of 326 position 1 to the source. Position 3 was in the end of the first train car and position 4 was in the 327 beginning of the second car. The figure shows some day-to-day variation in concentrations, which 328 is attributed to different engines, but overall it demonstrates a decrease in particle concentration 329 with increasing distance from the engine. 
Black carbon
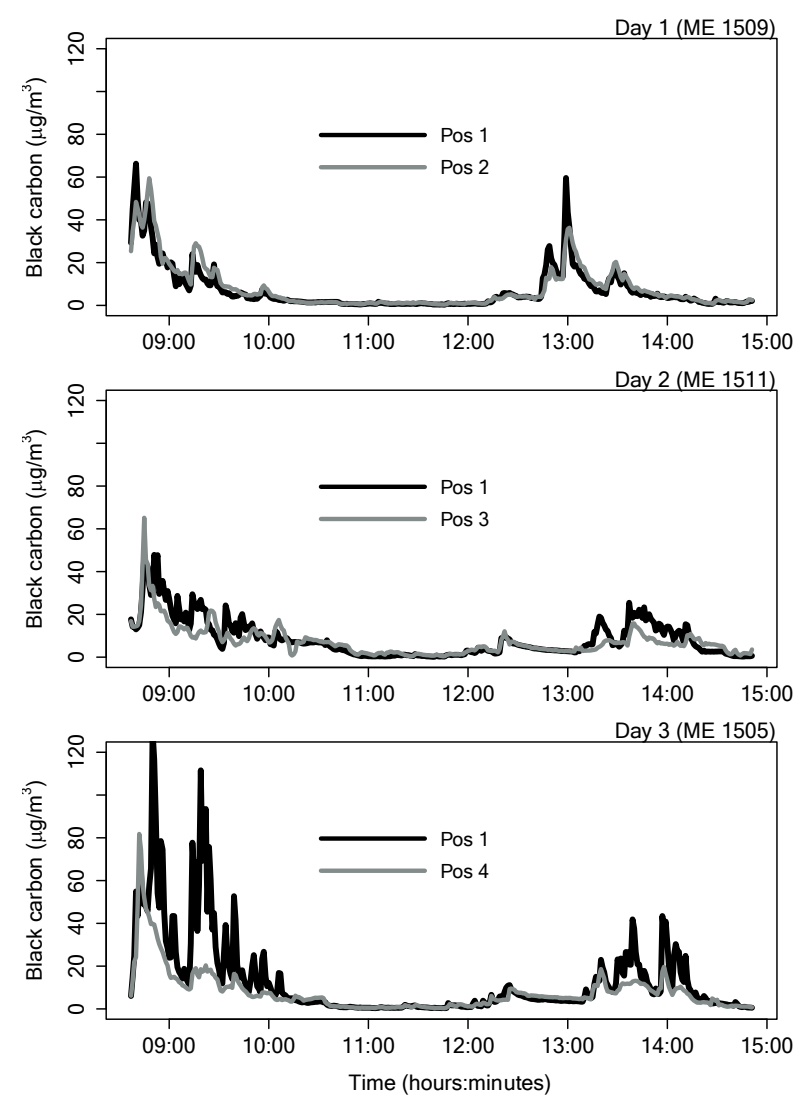

Ultrafine particles
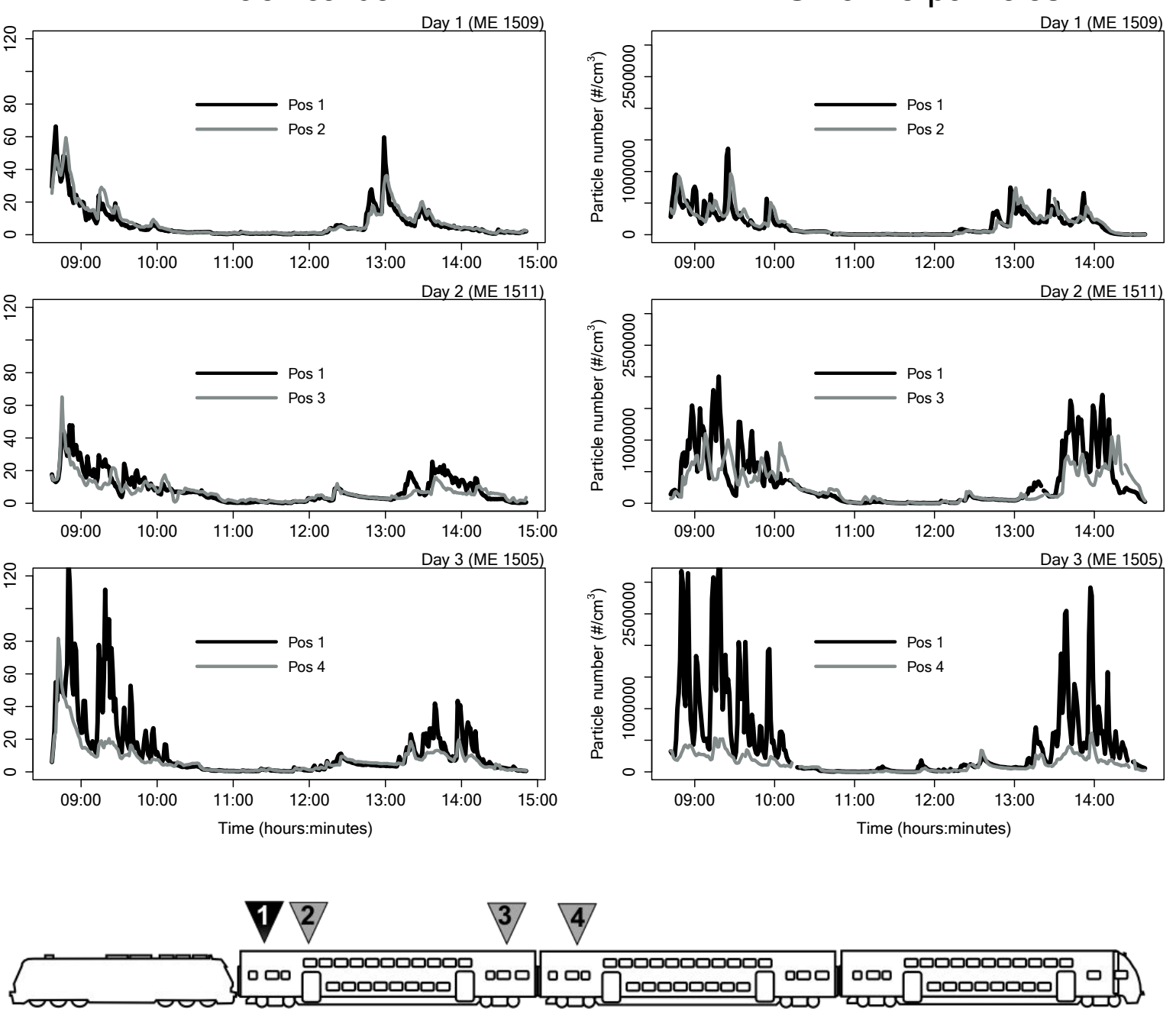

Figure 3 - Time-series data from BC and UFP concentrations (measured with DM) at four

positions inside the train during three days in December 2017 (Day 1, 13-12-2018; Day 2, 06-122018; Day 3, 07-12-2018). Position 1 was in the front section of the first passenger car of the diesel train, closest to the engine (Figure S2); position 2, was still in the first passenger car but partially separated from position 1 with a glass that partially confines the front section (without being closed); position 3, in the end of the first car; position 4, in the beginning of the second car. Some short interruptions in the position other than position 1 correspond to device restarts performed at stations. 
342 Figure 4 shows time-series of BC and UFP concentrations for two different days at Nørreport

343 station underground train platform. The BC mass and UFP number concentrations were 2.2-fold

344 and 4.5-fold higher, respectively, on the day the ME trains were in circulation (day 1) as compared

345 to the day when the ME trains were taken out due to maintenance (day 2). Data for both days were

346 recorded for the same time period and weekday, with slightly fewer trains in traffic in day 2

347 (Figure 5). For day 2 the "other diesel" train passages were the ones that seemed to contribute the most to both mass and number concentrations (Table S9 and Figures S7 and S8).
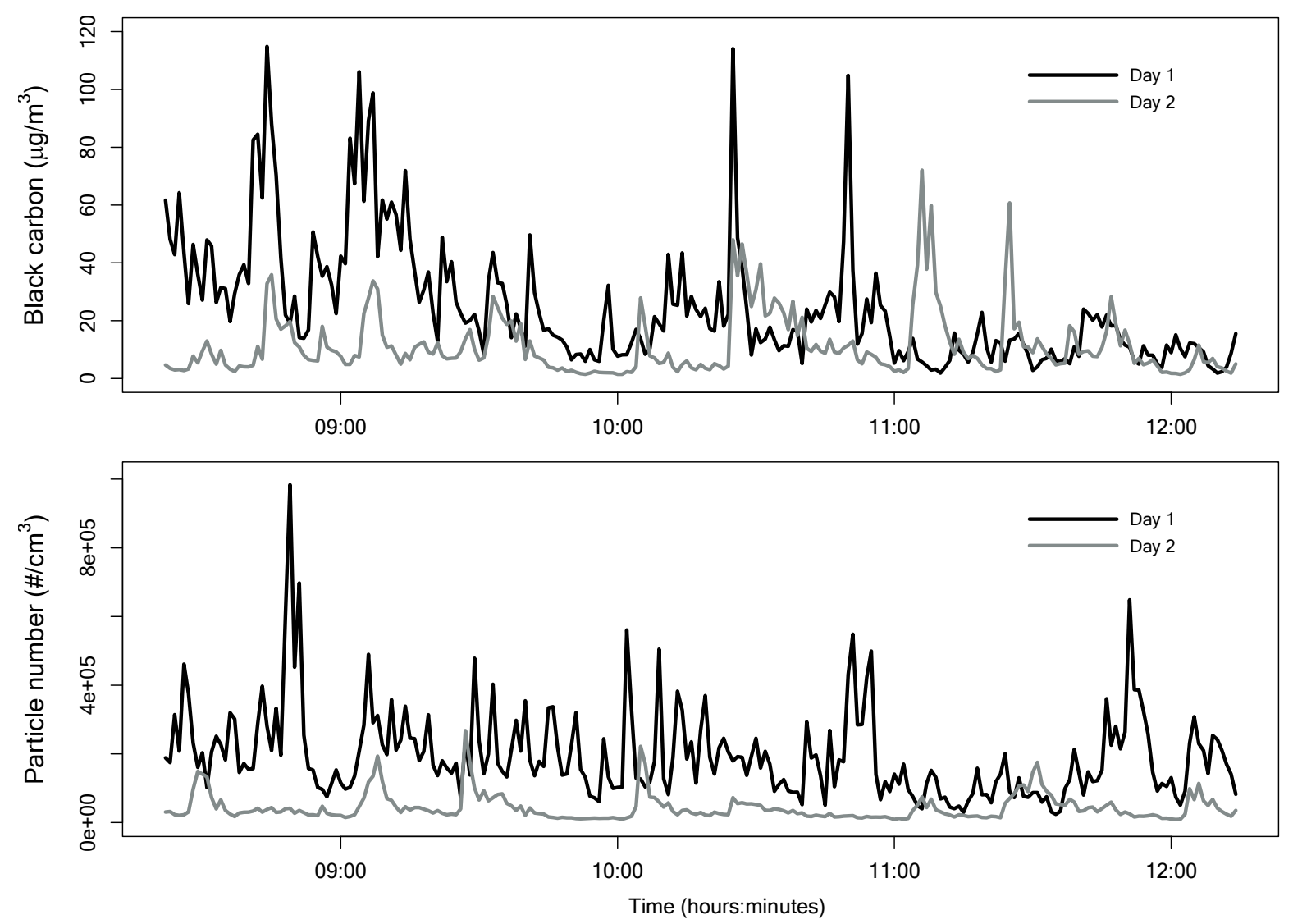

350 Figure 4- Time-series data from BC and UFP measured on underground train platform on two

351 different Fridays, with and without ME trains in circulation. Day 1, with ME trains in circulation

352 is represented in black colour and day 2, without the ME trains is represented in grey, both for time-series data with 1-minute resolution. 

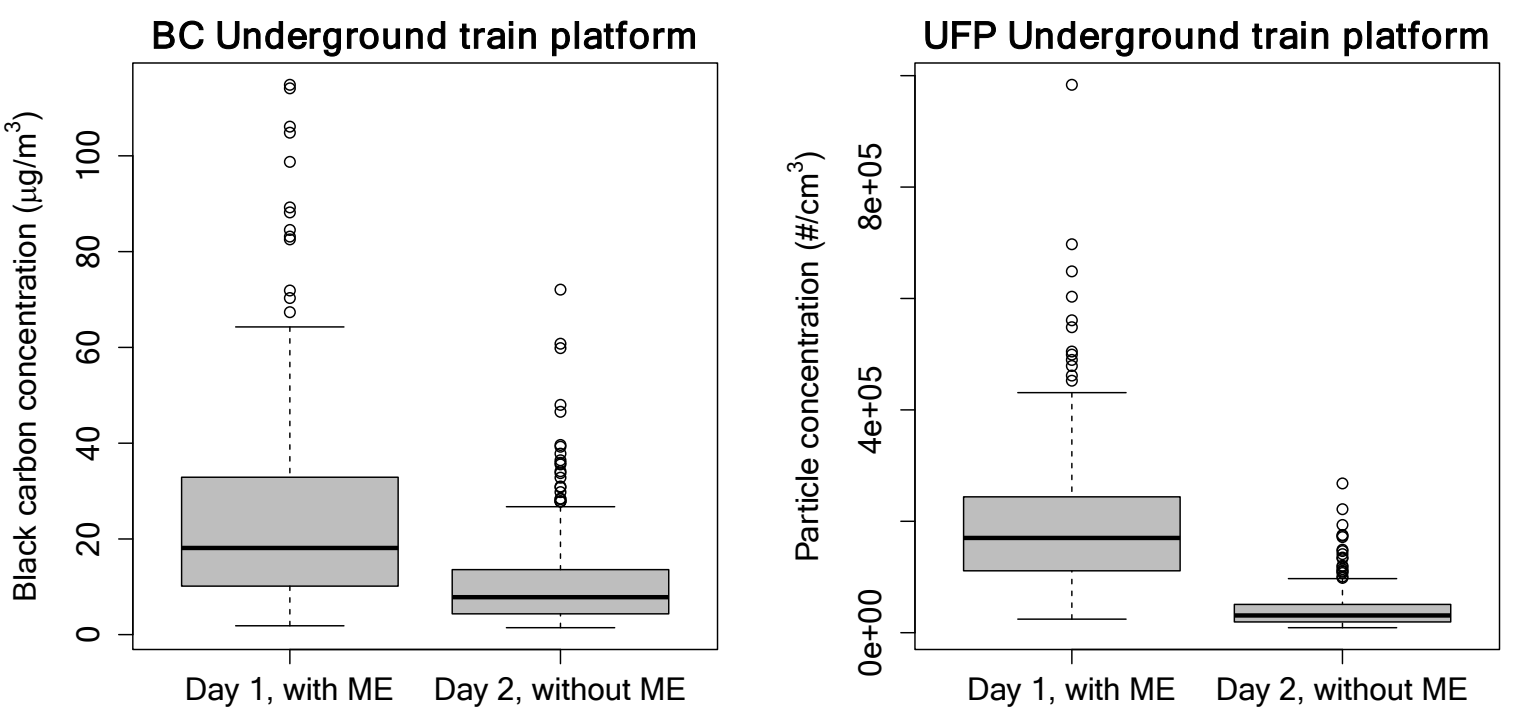

354

355

356

357

358

359

360

361

362

363

364

365

366

367

368

369

370

Figure 5- Underground train platform concentrations of black carbon mass (BC) and particle number (UFP) on two different days with and without ME trains in circulation. Day 1

(26/01/2018) had 111 train passages during the $4 \mathrm{~h}$ of measurements (37 ME, 14 other diesel and 60 electric trains). Day $2(02 / 02 / 2018)$ had 89 train passages during the $4 \mathrm{~h}$ of measurements $(20$ other diesel and 69 electric trains).

\section{Discussion}

Concentrations of UFP, $\mathrm{BC}, \mathrm{NOx}, \mathrm{NO}_{2}, \mathrm{PM}_{2.5}$ and $\mathrm{BaP}$ were higher in the passenger cars of diesel trains as compared to electric trains. Considerably higher concentrations of UFP and BC were measured when the locomotive was in pull mode. Our study presents a larger data set (more trips), covers a longer time period and measures more components of DE than previous studies ${ }^{4,7,19}$. It is also clear that older diesel trains contributed substantially to UFP and BC concentrations in an underground station in Copenhagen.

The average increase in air concentrations of UFP inside the diesel train (around 200,000 particles $/ \mathrm{cm}^{3}$ ) was considerably higher than the personal exposure measured during passive 
371 transport (car, bus or train), average 17,000 particles $/ \mathrm{cm}^{3}$, in a study of subjects in the general 372 population in Copenhagen ${ }^{20}$. For a daily commuter in diesel trains it would give a significant 373 contribution to the total exposure, depending on the time spent in transit. For train staff, the 374 average excess BC exposure of $8 \mu \mathrm{g} / \mathrm{m}^{3}$ would, if assumed it is equal to elemental carbon, for 8 375 hours workday give rise to around 160 excess lung cancer deaths per 10,000 individuals over a 376 lifetime, according to published exposure-response estimates ${ }^{12}$. Furthermore, environmental exposure to elemental carbon has been shown to increase the overall long-term mortality with around $6 \%$ per $1 \mu \mathrm{g} / \mathrm{m}^{3}$ increase at the residence ${ }^{19}$.

$\mathrm{BaP}$ is a potent carcinogen and air concentrations of $\mathrm{BaP}$ were 6-fold higher in diesel trains compared with electric trains (the same fold difference as for BC). The average concentrations of $\mathrm{BaP}$ in diesel trains $\left(0.17 \mathrm{ng} / \mathrm{m}^{3}\right)$ were higher than the reference level of $0.12 \mathrm{ng} / \mathrm{m}^{3}$ (lifetime exposure) based on the World Health Organization (WHO) unit risk for lung cancer for PAH mixtures (additional lifetime cancer risk of 1 per 100,000) ${ }^{21}$. The average concentrations of $\mathrm{PM}_{2.5}$ and $\mathrm{NO}_{2}$ were $68 \mu \mathrm{g} / \mathrm{m}^{3}$ and $53 \mu \mathrm{g} / \mathrm{m}^{3}$, respectively, inside the diesel trains. For a commuter who spends two hours per day travelling inside the first car of the diesel train, the average daily (24 hour) personal exposure to $\mathrm{PM}_{2.5}$ would increase from $15^{22}$ to $19 \mu \mathrm{g} / \mathrm{m}^{3}$ and for $\mathrm{NO}_{2}$ from $20^{22}$ to $23 \mu \mathrm{g} / \mathrm{m}^{3}$. The WHO air quality guidelines for $\mathrm{PM}_{2.5}$ is $25 \mu \mathrm{g} / \mathrm{m}^{3}$ for $24 \mathrm{~h}$ and $40 \mu \mathrm{g} / \mathrm{m}^{3}$ annual for $389 \mathrm{NO}_{2}$. The results from the real-time instruments (UFP and BC) showed that diesel exhaust enters the train passenger cars especially when the locomotive is in pull mode. It means that exposure to 393 diesel exhaust in train passenger cars can be reduced considerably by using push rather than pull 394 mode. Dramatic increases of UFP in pull compared with push mode have also been observed 395 inside passenger cars of diesel trains in Israel (3 to 43 fold higher concentrations, measured in 
396 different trains) ${ }^{4}$ and in Canada (18 times higher concentrations, average across 28 trips) ${ }^{7}$. From 397 the USA, the difference between pull and push mode was reported to be 3- and 9-fold in trains 398 from New York and Boston, respectively ${ }^{19}$. Overall, the mean concentrations of UFP inside diesel 399 trains in the present study were 20 and 35 times higher than in electric trains (measured with NT 400 and DM, respectively), which is a larger difference than reported from previous studies ${ }^{6}$. Average 401 concentrations of UFP and BC in first passenger car when locomotive was in pull mode in our 402 study were about 450,000 particles $/ \mathrm{cm}^{3}$ and $20 \mu \mathrm{g} / \mathrm{m}^{3}$, respectively, which is higher than reported 403 from Canada (UFP: $126,000 / \mathrm{cm}^{3}$ and BC: $\left.17.8 \mu \mathrm{g} / \mathrm{m}^{3}\right)^{7}$.

Another observation from our study is the elevated BC and UFP concentrations in the first morning trip, demonstrated in the diesel A scenario time-series where the same locomotive was used all day (Figure 1). Higher emissions in the morning might be attributable to a "cold" engine

408 having non-optimal combustion efficiency. The study also showed a decline in BC and UFP 409 concentrations from the passenger car proximal to the locomotive to the more distal train cars, 410 suggesting that infiltration of diesel exhaust in the first car is also spreading to other cars in the 411 train, however being diluted along the way. The gradient measurements were performed in 412 different days (different locomotives), which constitutes a limitation for the quantification and 413 comparison of concentrations at each position. This exposure study was carried out in relatively 414 old diesel trains from the 1980s and it may not be possible to extrapolate the observed results to 415 other diesel trains.

417 Cha and co-workers have reported a gradient in particle exposure inside electric railcars and noted 418 the importance of interior ventilation for indoor air quality 5 . For the trains in our study, ventilation 419 systems differ with season. In addition, there are two types of first passenger car in the double 420 deck rolling stock, as well as two types of diesel fuel (winter and summer diesel). We did not have 
421 enough information regarding ventilation to assess the impact on concentration levels, however

422 during the 49 monitoring days on diesel scenarios we covered both ventilation systems, double

423 deck cars and fuel type, and we always observed higher personal concentrations inside the

424 passenger car for diesel compared to electric trains.

426 We observed a tendency of increased $\mathrm{NO}_{2}$ concentrations in the end of the study, during winter, as 427 might be expected ${ }^{23,24}$, however we cannot conclude about any seasonal differences in relation to 428 other parameters. The particle number concentration also appeared to increase in the colder 429 months, but the contribution of the specific engine in use might be more important. As the trains 430 move as far as $114 \mathrm{~km}$ from Copenhagen, local precipitation and wind information have also been 431 difficult to investigate.

433 The aldehyde concentrations inside the trains were very low; however, the mean concentrations 434 were slightly elevated in diesel compared with electric trains. The formaldehyde concentrations

435 inside the trains were lower than the average personal exposure found among the general 436 population in Sweden $\left(19 \mu \mathrm{g} / \mathrm{m}^{3}\right)^{25}$, and lower than average concentrations found in Danish 437 dwellings $\left(20 \mu \mathrm{g} / \mathrm{m}^{3}\right)^{26}$.

439 The metal and metalloid elemental composition of the PM collected inside diesel trains showed 440 enrichment especially in iron, with other major elements being zinc, magnesium and copper.

441 Although with higher concentrations, the pattern is similar to the standard reference material 2975, 442 (Table S6) and also in comparison with other DE particulates ${ }^{27}$. The presence of silver was likely 443 attributed to the electrostatic sampler silver-coating ${ }^{28}$. 
445 The ME-locomotives will be replaced with new electric locomotives in 2021, according to a

446 public announcement ${ }^{29}$, nevertheless abatement actions should be put on place until then.

\section{Acknowledgments}

449 The technical assistance from Signe Nielsen, Ulla Tegner and Vivi Kofoed-Sørensen is gratefully

450 acknowledged. Special thanks go to Danish State Railways for all the logistical support. We are

451 also grateful to the volunteers carrying the monitoring devices for the considerable time and

452 willingness put into this study.

\section{Funding}

455 The research leading to these results has received funding from Danish Centre for Nanosafety II.

\section{Supporting information}

458 Measurement details; detailed output of NanoScan SMPS; UFP measured with NT; detailed

459 results from PAHs; detailed results from elemental analysis; and details of gradient and

460 underground measurements. This information is available free of charge via the Internet at

461 http://pubs.acs.org.

\section{References}

1. OECD/IEA and UIC Railway handbook 2017 - Energy consumption and CO2 emissions: foccus on passenger rail services; www.uic.org/uic-iea-railway-handbook, 2017; pp 1120.

2. Burchill, M. J.; Gramotnev, D. K.; Gramotnev, G.; Davison, B. M.; Flegg, M. B., Monitoring and analysis of combustion aerosol emissions from fast moving diesel trains. Sci Total Environ 2011, 409, (5), 985-93. 
3. Jaffe, D. A.; Hof, G.; Malashanka, S.; Putz, J.; Thayer, J.; Fry, J. L.; Ayres, B.; Pierce, J. R., Diesel particulate matter emission factors and air quality implications from in-service rail in Washington State, USA. Atmospheric Pollution Research 2014, 5, (2), 344-351.

4. Abramesko, V.; Tartakovsky, L., Ultrafine particle air pollution inside diesel-propelled passenger trains. Environ Pollut 2017, 226, 288-296.

5. Cha, Y.; Tu, M.; Elmgren, M.; Silvergren, S.; Olofsson, U., Factors affecting the exposure of passengers, service staff and train drivers inside trains to airborne particles. Environ Res 2018, 166, 16-24.

6. Knibbs, L. D.; Cole-Hunter, T.; Morawska, L., A review of commuter exposure to ultrafine particles and its health effects. Atmos Environ 2011, 45, (16), 2611-2622.

7. Jeong, C. H.; Traub, A.; Evans, G. J., Exposure to ultrafine particles and black carbon in diesel-powered commuter trains. Atmos Environ 2017, 155, 46-52.

8. Abbasi, S.; Jansson, A.; Sellgren, U.; Olofsson, U., Particle Emissions From Rail Traffic: A Literature Review. Crit Rev Env Sci Tec 2013, 43, (23), 2511-2544.

9. Cha, Y. Y.; Abbasi, S.; Olofsson, U., Indoor and outdoor measurement of airborne particulates on a commuter train running partly in tunnels. P I Mech Eng F-J Rai 2018, 232, (1), 3-13.

10. IARC Diesel and Gasoline Engine Exhausts and Some Nitroarenes.; World Health Organization - International Agency for Research on Cancer: www.ncbi.nlm.nih.gov/pubmed/26442290, 2014; pp 9-699.

11. Reis, H.; Reis, C.; Sharip, A.; Reis, W.; Zhao, Y.; Sinclair, R.; Beeson, L., Diesel exhaust exposure, its multi-system effects, and the effect of new technology diesel exhaust. Environment International 2018, 114, 252-265.

12. Vermeulen, R.; Silverman, D. T.; Garshick, E.; Vlaanderen, J.; Portengen, L.; Steenland, K., Exposure-Response Estimates for Diesel Engine Exhaust and Lung Cancer Mortality Based on Data from Three Occupational Cohorts. Environ Health Persp 2014, 122, (2), 172-177.

13. Karottki, G.; Loft, S. Rapport vedrørende måling af udsættelse for ultrafine partikler blandt ansatte i DSB; www.dsb.dk/om-dsb/samfundsansvar/miljo/ultrafine-partikler/ on 0810-2018, 2015; pp 1-48.

14. Madsen, A. M.; Sharma, A. K., Sampling of High Amounts of Bioaerosols Using a HighVolume Electrostatic Field Sampler. The Annals of Occupational Hygiene 2008, 52, (3), 167-176.

15. Hagenbjork-Gustafsson, A.; Tornevi, A.; Forsberg, B.; Eriksson, K., Field validation of the Ogawa diffusive sampler for NO2 and NOx in a cold climate. J Environ Monit 2010, 12, (6), 1315-24.

16. Kliucininkas, L.; Martuzevicius, D.; Krugly, E.; Prasauskas, T.; Kauneliene, V.; Molnar, P.; Strandberg, B., Indoor and outdoor concentrations of fine particles, particle-bound PAHs 
and volatile organic compounds in Kaunas, Lithuania. J Environ Monit 2011, 13, (1), 18291.

17. Andersen, M. H. G.; Saber, A. T.; Clausen, P. A.; Pedersen, J. E.; Løhr, M.; Kermanizadeh, A.; Loft, S.; Ebbehøj, N. E.; Hansen, Å. M.; Pedersen, P. B.; Koponen, I. K.; Nørskov, E.-C.; Møller, P.; Vogel, U., Association between polycyclic aromatic hydrocarbons exposure and peripheral blood mononuclear cell DNA damage in human volunteers during fire extinction exercises. Mutagenesis 2018, 33, 105-115.

18. R Core Team, R: A language and environment for statistical computing. In R Foundation for Statistical Computing, Vienna, Austria: www.R-project.org/, 2014.

19. Clean Air Task Force A multi-city investigation of exposure to diesel exhaust in multiple commuting modes.; www.catf.us/wpcontent/uploads/2019/02/CATF_Pub_Diesel_Exhaust_Exposure_Investigation.pdf, 2010; pp 1-84.

20. Beko, G.; Kjeldsen, B. U.; Olsen, Y.; Schipperijn, J.; Wierzbicka, A.; Karottki, D. G.; Toftum, J.; Loft, S.; Clausen, G., Contribution of various microenvironments to the daily personal exposure to ultrafine particles: Personal monitoring coupled with GPS tracking. Atmos Environ 2015, 110, 122-129.

21. WHO WHO guidelines for indoor air quality: selected pollutants.; World Health Organization: 2010.

22. Sorensen, M.; Loft, S.; Andersen, H. V.; Raaschou-Nielsen, O.; Skovgaard, L. T.; Knudsen, L. E.; Nielsen, I. V.; Hertel, O., Personal exposure to PM2.5, black smoke and NO2 in Copenhagen: relationship to bedroom and outdoor concentrations covering seasonal variation. J Expo Anal Environ Epidemiol 2005, 15, (5), 413-22.

23. Grundström, M.; Linderholm, H. W.; Klingberg, J.; Pleijel, H., Urban NO2 and NO pollution in relation to the North Atlantic Oscillation NAO. Atmos Environ 2011, 45, (4), 883-888.

24. Roberts-Semple, D.; Song, F.; Gao, Y., Seasonal characteristics of ambient nitrogen oxides and ground-level ozone in metropolitan northeastern New Jersey. Atmospheric Pollution Research 2012, 3, (2), 247-257.

25. Hagenbjork-Gustafsson, A.; Tornevi, A.; Andersson, E. M.; Johannesson, S.; Bellander, T.; Merritt, A. S.; Tinnerberg, H.; Westberg, F.; Forsberg, B.; Sallsten, G., Determinants of personal exposure to some carcinogenic substances and nitrogen dioxide among the general population in five Swedish cities. J Expo Sci Env Epid 2014, 24, (4), 437-443.

26. Raaschou-Nielsen, O.; Hermansen, M. N.; Loland, L.; Buchvald, F.; Pipper, C. B.; Sorensen, M.; Loft, S.; Bisgaard, H., Long-term exposure to indoor air pollution and wheezing symptoms in infants. Indoor Air 2010, 20, (2), 159-167.

27. Loxham, M.; Cooper, M. J.; Gerlofs-Nijland, M. E.; Cassee, F. R.; Davies, D. E.; Palmer, M. R.; Teagle, D. A. H., Physicochemical Characterization of Airborne Particulate Matter at a Mainline Underground Railway Station. Environ Sci Technol 2013, 47, (8), 3614-3622. 
28. Sharma, A. K.; Wallin, H.; Jensen, K. A., High volume electrostatic field-sampler for collection of fine particle bulk samples. Atmos Environ 2007, 41, (2), 369-381.

29. DSB Fremtidens tog - beslutningsoplæg for Fase 1.5;

551 https://www.dsb.dk/globalassets/om-dsb/rapporter/fremtidenstog/beslutningsoplag-for-fase-1.5.pdf on 06-01-2019, 2017.

553 